Check for updates

Tenterden, UK

Cite this as: BMJ 2021;373:n1086 http://dx.doi.org/10.1136/bmi.n1086 Published: 26 April 2021

\section{Covid-19: Countries rally to support India through "storm that has shaken the nation"}

\author{
Jacqui Wise
}

Countries around the world have pledged to help India as the country continues to see an exponential rise in covid-19 cases and deaths, with hospitals running out of oxygen, drugs, and beds.

India reported a record high of 352991 daily confirmed covid-19 cases and 2812 deaths on 25 April, according to the Johns Hopkins University database. ${ }^{1}$ This brings the cumulative total of deaths to 195123 , although the true figure is believed to be much higher.

Hospitals in India have been pleading publicly for help as they run out of oxygen. At least 20 covid-19 patients died at the private Jaipur Golden Hospital in North west Delhi following a dip in oxygen pressure. ${ }^{2}$ India's crematoriums and burial grounds are reported to be overwhelmed. ${ }^{3}$

In a radio address on 25 April, Prime Minister Narendra Modi urged people to be vaccinated and exercise caution, saying, "Our spirits were up after successfully tackling the first wave, but this storm has shaken the nation."

The UK announced it is sending nine airline container loads of supplies to India, including 495 oxygen concentrator devices, 120 non-invasive ventilators, and 20 manual ventilators. The first shipment is to arrive in New Delhi on 27 April with further shipments to follow later in the week. 4

Officials in the US said they have identified sources of specific raw material urgently required for Indian manufacture of the Covishield vaccine that will immediately be made available for India. ${ }^{5}$ The country is also funding a substantial expansion of manufacturing capability at the vaccine manufacturer BioE, enabling it to produce at least 1 billion doses of covid-19 vaccines by the end of 2022. Therapeutics, rapid diagnostic test kits, ventilators, and personal protective equipment (PPE) are also being sent from US.

There have been a number of appeals for the US to send India its stockpile of the AstraZeneca vaccine that is sitting unused in warehouses, however there is no indication that this will happen.

President Joe Biden wrote on Twitter: "Just as India sent assistance to the US as our hospitals were strained early in the pandemic, we are determined to help India in its time of need."

Responding to the crisis, Singapore and Saudi Arabia have sent tanks of liquid oxygen and Germany has sent 23 mobile oxygen generation plants. Ursula von der Leyen, the European Commission president, said the EU was "pooling resources to respond rapidly to India's request for assistance.”
Pakistan's government has also pledged to send ventilators and other medical equipment to its arch rival as a "gesture of solidarity." China's foreign ministry spokesperson, Shao Lijian, said that Beijing is "ready to provide support and help."

The World Medical Association unanimously backed an emergency motion calling for urgent action to support countries hardest hit by the virus including India and Brazil. ${ }^{6}$ The motion, put forward by the BMA, called on the international community and governments to "urgently prioritise support and aid to the worst affected nations, including oxygen, drugs, vaccines, PPE, and other equipment as needed, and to strengthen healthcare system resilience in the face of future pandemics."

Chaand Nagpaul, BMA council chair, said, "It is alarming and saddening to see the devastation covid-19 is inflicting on some countries, their healthcare services, dedicated staff, and, most importantly, their patients." He added, “The only way we will defeat this pandemic is if we tackle the virus in every corner of the globe, standing alongside one another and offering support and aid to the worst affected nations at any moment in time."

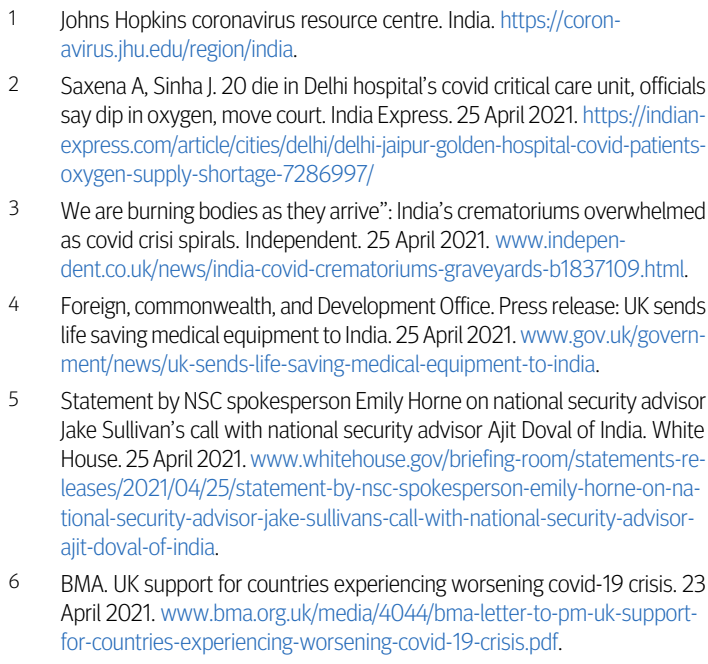

2 Saxena A, Sinha J. 20 die in Delhi hospital's covid critical care unit, officials say dip in oxygen, move court. India Express. 25 April 2021. https://indianexpress.com/article/cities/delhi/delhi-jaipur-golden-hospital-covid-patientsoxygen-supply-shortage-7286997/

3 We are burning bodies as they arrive": India's crematoriums overwhelmed as covid crisi spirals. Independent. 25 April 2021. www. independent.co.uk/news/india-covid-crematoriums-graveyards-b1837109.html.

4 Foreign, commonwealth, and Development Office. Press release: UK sends life saving medical equipment to India. 25 April 2021. www.gov.uk/government/news/uk-sends-life-saving-medical-equipment-to-india.

5 Statement by NSC spokesperson Emily Horne on national security advisor Jake Sullivan's call with national security advisor Ajit Doval of India. White House. 25 April 2021. www. whitehouse.gov/briefing-room/statements-releases/2021/04/25/statement-by-nsc-spokesperson-emily-horne-on-national-security-advisor-jake-sullivans-call-with-national-security-advisorajit-doval-of-india.

6 BMA. UK support for countries experiencing worsening covid-19 crisis. 23 April 2021. www.bma.org.uk/media/4044/bma-letter-to-pm-uk-supportfor-countries-experiencing-worsening-covid-19-crisis.pdf.

This article is made freely available for use in accordance with BMJ's website terms and conditions for the duration of the covid-19 pandemic or until otherwise determined by BMJ. You may use, download and print the article for any lawful, non-commercial purpose (including text and data mining) provided that all copyright notices and trade marks are retained. 